\title{
Review \\ On the Role of Central Type-1 Cannabinoid Receptor Gene Regulation in Food Intake and Eating Behaviors
}

\author{
Mariangela Pucci ${ }^{1,2, * \mathbb{D}}$, Elizabeta Zaplatic ${ }^{1}$, Maria Vittoria Micioni Di Bonaventura ${ }^{3}$ (D),

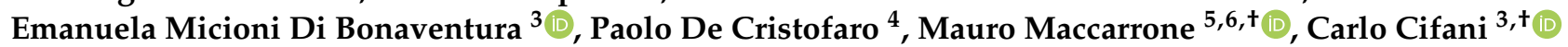 \\ and Claudio $\mathrm{D}^{\prime}$ Addario $1,7, *,+$
}

check for

updates

Citation: Pucci, M.; Zaplatic, E.; Micioni Di Bonaventura, M.V.; Micioni Di Bonaventura, E.;

De Cristofaro, P.; Maccarrone, M.; Cifani, C.; D'Addario, C. On the Role of Central Type-1 Cannabinoid Receptor Gene Regulation in Food Intake and Eating Behaviors. Int. J. Mol. Sci. 2021, 22, 398. https:// doi.org/10.3390/ijms22010398

Received: 20 November 2020 Accepted: 18 December 2020 Published: 1 January 2021

Publisher's Note: MDPI stays neutral with regard to jurisdictional clai$\mathrm{ms}$ in published maps and institutional affiliations.

Copyright: (C) 2021 by the authors. Licensee MDPI, Basel, Switzerland. This article is an open access article distributed under the terms and conditions of the Creative Commons Attribution (CC BY) license (https:// creativecommons.org/licenses/by/ $4.0 /)$.
1 Faculty of Bioscience and Technology for Food, Agriculture and Environment, University of Teramo, 64100 Teramo TE, Italy; ezaplatic@unite.it

2 Department of Biosciences and Nutrition, Karolinska Institutet, 14183 Huddinge, Sweden

3 Pharmacology Unit, School of Pharmacy, University of Camerino, 62032 Camerino MC, Italy; mariavittoria.micioni@unicam.it (M.V.M.D.B.); emanuela.micioni@unicam.it (E.M.D.B.); carlo.cifani@unicam.it (C.C.)

4 Clinical Endocrinology and Metabolism Outpatient Clinic, 64021 Giulianova TE, Italy; pdecristofaro@gmail.com

5 Department of Biotechnological and Applied Clinical Sciences, University of L'Aquila, 67100 L'Aquila AQ, Italy; mauro.maccarrone@univaq.it

6 European Center for Brain Research, Santa Lucia Foundation IRCCS, 00179 Rome RM, Italy

7 Department of Clinical Neuroscience, Karolinska Institutet, 17176 Stockholm, Sweden

* Correspondence: mpucci@unite.it (M.P.); cdaddario@unite.it (C.D.)

+ Equally senior authors.

\begin{abstract}
Different neuromodulatory systems are involved in long-term energy balance and body weight and, among these, evidence shows that the endocannabinoid system, in particular the activation of type- 1 cannabinoid receptor, plays a key role. We here review current literature focusing on the role of the gene encoding type- 1 cannabinoid receptors in the CNS and on the modulation of its expression by food intake and specific eating behaviors. We point out the importance to further investigate how environmental cues might have a role in the development of obesity as well as eating disorders through the transcriptional regulation of this gene in order to prevent or to treat these pathologies.
\end{abstract}

Keywords: type-1 cannabinoid receptor gene; transcriptional regulation; food intake; eating behaviors

\section{Central Regulation of Food Intake and the Role of Cannabinoid Receptor Type-1}

Food intake might be considered the integration of humoral and neuronal signals processed by the nervous system for the balance of energy and of sensory cues, as well as of the motivational and emotional state of an individual. Thus, different eating behaviors are finely driven by both homeostatic and hedonic signals, whose functions may vary between individuals according to previous experiences and/or epigenetic variations [1-7].

Homeostatic and hedonic central circuitries are interconnected, in fact feeding behaviors are affected by brain regions classically viewed as mainly involved in homeostatic feeding; however, these are also influenced by brain corticolimbic and hedonic areas, and vice versa $[8,9]$. The homeostatic feeding will be terminated once the organism is repleted with energy and nutrients, while hedonic feeding might continue. An imbalance toward the hedonic aspect of feeding without restriction may provoke changes in the food intake with serious consequences on the weight gain/loss [10,11].

The hypothalamus (HYP) is the center for the integration and control of essential bodily functions, such as circadian rhythm, body temperature and plasma-osmolarity, and traditionally recognized as the main brain region regulating food intake. It regulates feeding as a function of caloric and nutritional requirements, by sensing macronutrients 
and through the action of circulating regulatory hormones, neuropeptides and neuromodulators, such as leptin, cholecystokinin, ghrelin, orexin/hypocretin, insulin, neuropeptide $\mathrm{Y}$, and notably lipid signals like endocannabinoids [12-15]. The imbalance in hypothalamic function may provoke an altered food intake, potentially leading to eating disorders (EDs) and obesity [16-18].

Besides HYP, several limbic brain areas including ventral tegmental area, nucleus accumbens (NAc), amygdala, and hippocampus, as well as cortical brain regions, have also been implicated in the hedonic aspects of feeding [19-21].

Studies on the role played by the reward circuits in defining hedonic aspects of feeding allowed to define how common mechanisms are shared by drug abuse and food addiction [22-24]. Both are compulsive behavioral disorders that induce alterations in brain mechanisms underlying synaptic plasticity and energy homeostasis, showing common vulnerabilities and pathophysiological aspects [25].

Among the different neuromodulatory systems involved in long-term energy balance and body weight regulation, many preclinical and clinical evidence show the key role of the endocannabinoid system (ECS) [26], and in particular, the activation of type-1 cannabinoid receptors $\left(\mathrm{CB}_{1} \mathrm{R}\right)[27,28]$.

Indeed, several preclinical studies show that orexigenic stimuli induce $\mathrm{CB}_{1} \mathrm{R}$ activation in the rat brain, specifically in the HYP $[29,30]$ where $C_{1} R$ positive neurons are present in different nuclei [31], although at low density [32], and support a role in food and energy balance [33-36]. Brain reward pathways are largely responsible for processing information related to the motivation, expectation, and pursuit of pleasurable experiences, and $\mathrm{CB}_{1} \mathrm{R}$ signaling was reported to modulate dopaminergic signaling in the ventral tegmental area and NAc to control hedonic eating [37-40]. $\mathrm{CB}_{1} \mathrm{R}$ signaling also plays a role in the functional activity of caudal brainstem nuclei: parabrachial nucleus, nucleus of the solitary tract, and dorsal motor nucleus of the vagus nerve. Herein, $\mathrm{CB}_{1} \mathrm{R}$ mainly controls food preferences, e.g., digestion of fat rich palatable food [37]. Several experimental findings already pointed to $\mathrm{CB}_{1} \mathrm{R}$ as therapeutic target to treat altered feeding behavior and obesity $[30,34,41,42]$, due to the hyperphagic role of this receptor, and the possible exploitation of its pharmacological blockade, as recently reviewed [43]. It should be recalled that rimonabant, a $\mathrm{CB}_{1} \mathrm{R}$ antagonist/inverse agonist [44], entered the European mass market, showing weight loss benefits but it was soon withdrawn due to the significant side effects [45]. Here, we focused mainly on the role of type-1 Cannabinoid Receptor gene (CNR1) gene, which encodes for $\mathrm{CB}_{1} \mathrm{R}$, and its regulation in food intake and eating behaviors.

\section{CNR1 Gene}

$\mathrm{CB}_{1} \mathrm{R}$ is one of the most abundant seven transmembrane $\mathrm{G}$ protein-coupled receptor of the class A [46]. It is prominently expressed in the central nervous system (CNS) [47] and has attracted great attention as a modulator of different brain functions including appetite, fear, anxiety and pain [48-50]. The ECS, as a whole, is comprised of (1) the endocannabinoids (eCBs) anandamide ( $N$-arachidonoyl-ethanolamine) and 2-arachidonoylglycerol, which are physiological ligands for cannabinoid and non-cannabinoid receptors; (2) the cannabinoid receptors and non-cannabinoid receptors, such as transient receptor potential vanilloid 1 channels [51,52]; and (3) enzymes responsible for the biosynthesis and hydrolysis of eCBs. Biosynthetic routes are mediated by $N$-acylphosphatidylethanolamines-specific phospholipase D, diacylglycerol lipase, phosphoinositide-specific PLC and lyso-PLC, while termination of $\mathrm{eCB}$ signaling is terminated through the action of purported transmembrane transporters, followed by hydrolysis by fatty acid amide hydrolase (FAAH) and monoacylglycerol lipase [50].

$\mathrm{CB}_{1} \mathrm{R}$ was first cloned in 1990 and was immediately recognized as the receptor responsible for the effects of marijuana on CNS; it was also reported to be more responsive to psychoactive than non-psychoactive cannabinoids [53]. $\mathrm{CB}_{1} \mathrm{R}$ is encoded by CNR1 gene, and consists of 472 amino acids in humans, and 473 amino acids in rats and mice, with 
97-99\% amino acid sequence identity among them [54] (Figure 1). CNR1 gene is located on human chromosome 6q14-15 [55] and its gene sequence is composed of four exons, with exon 4 containing the entire protein coding region.

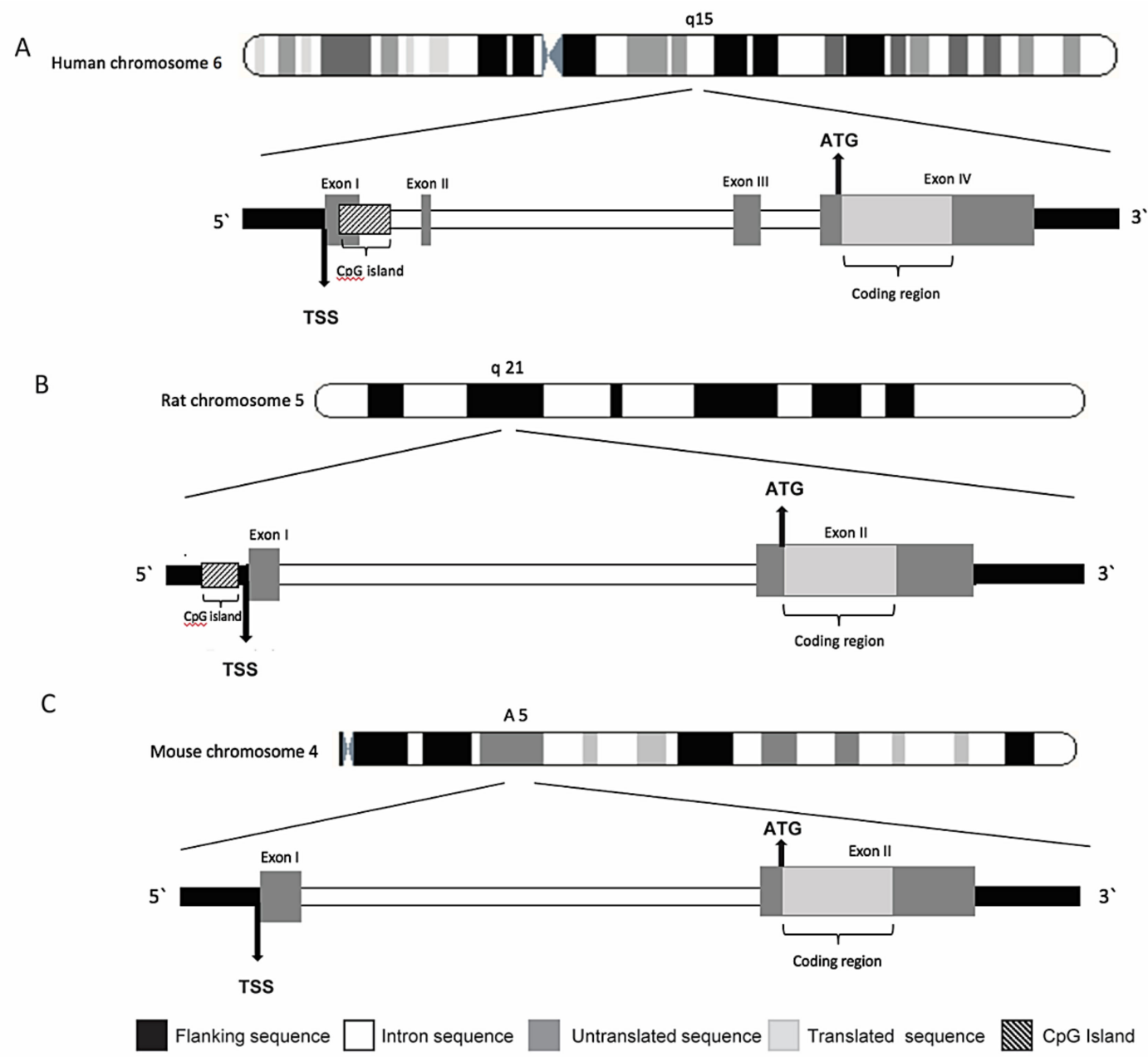

Figure 1. Schematic representation of human(A), rat (B) and mouse (C) CNR1 gene, with their cromosomial locations.

Also, in mice and rats the coding region of CNR1 is contained within a single exon. However, the $5^{\prime}$ untranslated region (5'-UTR) and promoter structures differ between mice and humans [56,57], and these structures are not described in rats [58]. Alternative splicing of portions outside the coding region yields six different $5^{\prime}$-UTR splicing variants. In addition, it appears that multiple transcription starting sites exist within the first 60 base pairs (bp) of the first exon [59]. Three $C N R 1$ coding region variants for $\mathrm{CB}_{1} \mathrm{R}$ protein isoforms have been identified in humans and non-human primates: (1) the intronless 472 amino acid-long protein, the one known as $\mathrm{CB}_{1} \mathrm{R}$, (2) the 411 amino acid-long protein, marked as $C_{1} R a$ and (3) the 439 amino acid-long protein, marked as $C_{1} B_{1} R b$ [60-62]. Some evidence indicated that $\mathrm{CB}_{1}$ Ra may also be expressed in the rat brain [59]. Several natural polymorphisms of the human gene have been identified, associated with different responsiveness to cannabinoids [57,63-67]. Alternative splice variants have also been reported, including the canonical long form expressed predominantly in the brain and skeletal muscle and two isoforms with shorter $\mathrm{N}$-terminus, one of which is highly expressed in the liver and pancreatic islet cells where it is involved in metabolic processes $[62,68,69]$. $\mathrm{CB}_{1} \mathrm{R}$ displays conserved spatial distribution in the CNS among different mammalian species [70]. In the brain, the majority of $\mathrm{CB}_{1} \mathrm{R}$ expressing cells are neurons. In the cortex and in the hippocampus high $\mathrm{CB}_{1} \mathrm{R}$ expressing cells are GABAergic neurons, whereas glutamatergic principal neurons express $\mathrm{CB}_{1}$ Rs on a lower level [71], while glial cells and 
astrocytes exhibit only the marginal expression [72,73]. Localization of $\mathrm{CB}_{1} \mathrm{R}$ in the brain, correlated with its role in the control of motor function, analgesia, cognition and memory, is abundant in the cortex, hippocampus, basal ganglia nuclei and cerebellum [46,74-77]. $\mathrm{CB}_{1} \mathrm{R}$ is also expressed in peripheral tissues like heart, uterus, testis, liver and small intestine, as well as in immune cells [78-80] and adipose tissue [81]. In a model of insulin resistance, CNR1 gene was identified as one of the genes with the greatest increase in expression in adipose tissue [82].

\subsection{CNR1 Gene in the Control of Energy Homeostasis and Obesity}

Circuits in the HYP regulate appetite and energy homeostasis [83] and a key role is played by hypothalamic $\mathrm{CB}_{1} \mathrm{R}$ signaling intertwined with the pathways of metabolic hormones. In fact, for instance, the reduced hypothalamic eCB levels are associated with appetite suppression by leptin [26], while the increased hypothalamic eCB levels are correlated with orexigenic actions of ghrelin, with the involvement of the activation of AMP-activated protein kinase and the inhibition of paraventricular neurons [84].

Using mice lacking CNR1 gene, it has been documented that eCBs actions on food intake and body weight depend on the functional expression and activity of $\mathrm{CB}_{1} \mathrm{R}$ [85]. In this work, Cota and colleagues demonstrated that germline deletion of CNR1 in male mice resulted in a phenotype characterized by decreased body weight, reduced fat mass, and hypophagia. Moreover, the study highlighted that CNR1 mRNA is co-expressed in the HYP with neuropeptides known to modulate food intake [85].

A significantly reduction in body weight was also reported in mice, where CNR1 gene expression was selectively deleted in the HYP, after 9 weeks of viral-mediated deletion. This effect, without any changes in food intake, suggested an increase in energy expenditure [86]. Further, adult mice, in which CNR1 gene was deleted in adipocytes, resulted to be protected from diet-induced obesity and associated with metabolic alterations [87].

Again, conditional mutant mice, with CNR1 deletion in forebrain and sympathetic neurons, known to control energy balance, are resistant to diet-induced obesity and display a lean phenotype [88].

Moreover, the relevant role of $\mathrm{CB}_{1} \mathrm{R}$ in the initiation of milk suckling in pups has been observed $[89,90]$ and, in particular, CNR1-knock-out $(\mathrm{KO})$ newborns did not ingest milk on the first day of life, significantly affecting their survival rate [90].

Furthermore, central dysregulation of CNR1 gene expression has been documented in animal models of obesity in different brain areas, implicated in both homeostatic and hedonic aspects of eating [91-93].

In particular, the exposure to a palatable diet resulted in tissue and sex-specific changes in the gene expression of both $\mathrm{CB}_{1} \mathrm{R}$ and type-2 cannabinoid receptor $\left(\mathrm{CB}_{2} \mathrm{R}\right)$ in the HYP of offspring and adults. These results clearly indicate that the maternal diet has long-term effects on the development of pups through multiple alterations of signaling homeostatic pathways that include cannabinoid receptors [93].

Gamelin and colleagues (2016) found in the hippocampus of rats, fed with High Fat Diet (HFD), an increase in the CNR1 mRNA expression compared to rats fed with standard diet. The up-regulation of hippocampal CNR1 expression was increased with exercise training combined with HFD. Indeed, chronic exercise did not appear to counteract ECS overactivation and, in fact, seems even to induce this effect independently from diet. Moreover, the authors showed that CNR1 expression in the HYP is not affected by HFD in rats [91].

It was also reported, in rats exposed to HFD, the reduction in $\mathrm{CB}_{1} \mathrm{R}$ binding sites in extrahypothalamic brain regions and $\mathrm{CB}_{1} \mathrm{R}$ density was related to the intake of palatable food, whereas no changes have been observed in the HYP [94]. This does not exclude transient changes in $\mathrm{CB}_{1} \mathrm{R}$ levels or $C N R 1$ expression over time. Indeed, a transient increase in mouse hypothalamic $\mathrm{CB}_{1} \mathrm{R}$ density, after 3 weeks of $\mathrm{HFD}$, was normalized at the end of the 20 weeks of $\mathrm{HFD}$, suggesting a temporal $\mathrm{CB}_{1} \mathrm{R}$ alteration during the development of obesity [95]. A temporal transcriptional regulation of CNR1 gene was also proved 
in the HYP of rats exposed to diet-induced obesity. The analysis of ECS components gene expression revealed a significant and selective increase in CNR1 mRNA levels at the beginning of obesity development ( 5 weeks on HFD) as well as after 21 weeks of exposure, when the phenotype was already well-established. Moreover, a consistent selective and significant reduction in DNA methylation at specific Cytosine-phosphate-Guanine (CpG) sites of CNR1 gene promoter in overweight rats was observed just after 5 weeks, but not 21 weeks on HFD [92].

In the same study, the DNA methylation status of CNR1 gene was assessed in peripheral blood mononuclear cells from a subset of obese human subjects. An age-based stratification of DNA methylation levels showed a significant reduction of the epigenetic hallmark at CNR1 promoter in younger ( $<30$ years old) humans with obesity, when compared to age-matching controls. These findings suggest that the regulation of CNR1 gene is altered mainly at early life stage of phenotype development [92].

Considering other epigenetic modifications possibly occurring in the development of obesity, recently a hypothalamic increase in histone acetylation was reported at CNR1 gene promoter and was linked to increased receptor expression [96]. Almeida and colleagues hypothesized that maternal fat enriched diet would up-regulate CNR1 mRNA levels in the HYP of the male offspring at birth [96].

These latter findings support the relevance of environment and lifestyle in the facilitation of diseases progression, including obesity, by engaging epigenetic mechanisms [97], and in meantime could represent an innovative field to produce new strategies of intervention.

Genetic studies have identified several polymorphisms at different locations across the CNR1 gene that have been associated with obesity and related phenotypes, such as metabolic syndrome and dyslipidemia [98-106].

Among others, particular attention has been focused on a silent intragenic biallelic polymorphism in codon 435 of CNR1 gene, substitution of $\mathrm{G}$ to $\mathrm{A}$ at nucleotide position 1359 (1359 G/A rs1049353) [107]. This Single Nucleotide Polymorphism (SNP) was reported to be associated with abdominal adiposity [108], Body Mass Index (BMI) [109], intermuscular fat mass [110], and longitudinal changes from healthy to metabolic syndrome occurrence [111]. However, the literature has been inconsistent with respect to CNR1 polymorphisms and obesity-related markers, with many studies not finding any relevant association with CNR1 gene variants [112-114].

\subsection{CNR1 Gene in Eating Disorders}

EDs, defined in the Diagnostic and Statistical Manual of Mental Disorders (DSM)V [115], represent a group of conditions characterized by abnormal appetite and eating patterns, accompanied with other physiological as well as psychological disturbances.

The principal mechanisms implicated in the etiology of EDs involve dysregulation of neuronal circuits regulating homeostatic and hedonic aspects of food intake, thus including the ECS signaling.

Candidate gene association studies revealed the association of ECS genes SNPs in EDs. Specific genetic variants of CNR1, again rs1049353, as well as FAAH genes were identified in individuals with Anorexia Nervosa (AN) and Bulimia Nervosa (BN) [116], even if an earlier study failed to find associations of the same SNPs in a different AN population [114]. Although CNR1 rs1049353 is synonymous or silent, thus, not altering the amino acid sequence of the protein, Monteleone et al. suggested that it might have functional effects by changing mRNA stability or translation as already proposed for other SNPs [117]. Moreover, rs1049353 was found associated with lower BMI with unexplained heterogeneity within the human cohort [107].

A microsatellite polymorphism, namely an AAT (adenine-adenine-thymine) trinucleotide short tandem repeat (AAT)n, is present at CNR1 gene downstream the translation site [57]. It is known that microsatellites might affect transcription efficacy in some genes [118]. This AAT trinucleotide repeat has been found to be associated with restricting and bingeing/purging AN [119]. 
CNR1 KO mice display significant body weight loss under standard diet, a resistance to the obesogenic effects of the HFD and a reduced food intake on both diet regimens [120] further supporting the specific association of CNR1 gene with hypophagia [121,122]. Furthermore, preclinical studies in the Activity-based anorexia (ABA) rat model, found a reduced density of $\mathrm{CB}_{1} \mathrm{Rs}$ in lateral HYP and dental gyrus of the hippocampus [123] and, consistently, it was recently reported the reduction in CNR1 gene expression in HYP as well as NAc in ABA rats [124]. It has been suggested that the decrease in $C_{1} R$ density might be driven by the decrease in eCBs that are necessary for receptor expression [125]. However, others reported increased $C_{1} R$ availability in ABA rats [126], as well as in AN $[127,128]$ and BN patients [128]. Gerard et al. suggested that in AN, this might act as compensatory mechanisms to chronically hypoactive ECS. Interestingly, short-term starvation increased hypothalamic 2-arachidonoylglycerol concentration in animals [129], whereas a long-term food-restriction (12 days protocol in mice) resulted in whole brain decrease of 2-arachidonoylglycerol [130]. There might occur adaptive strategies for coping with short- and long-lasting food deprivation, as elevated eCB levels might be beneficial to promote food seeking behavior in short term, while down-regulation of this orexigenic signal and reduction of appetite and motivation to eat may aid survival in the conditions of prolonged starvation [131]. Thus, the down-regulation of CNR1 gene expression might be a compensation for a purported reduced sensitivity of the receptor or a physiological consequence of up-regulated eCBs in these disorders [132]. Following to that, a recent study reported that $\mathrm{CB}_{1} \mathrm{R}$ availability was inversely associated with $\mathrm{BMI}$ in homeostatic brain regions of HYP and brainstem both in ED patients and healthy controls, while in the mesolimbic reward system (amygdala, insula, midbrain, striatum, and orbitofrontal cortex), negative correlation was found only in EDs patients [133]. The ECS deviations in homeostatic brain regions most likely present compensatory mechanism aimed at restoring energy balance, while alterations in brain areas implicated in motivation and reward may reflect disordered hedonic eating behavior observed in AN patients.

Endocannabinoids are also implicated in psychiatric comorbidities common in AN, such as anxiety and depression. Chronic stress, anxiety and depression exhibit $\mathrm{CB}_{1} \mathrm{R}$ deficiency and reduced $\mathrm{CB}_{1} \mathrm{R}$-mediated signaling [134,135], while blockade or genetic deletion of $\mathrm{CB}_{1}$ Rs has anxiogenic properties [136]. Furthermore, depression in human patients has been linked with several polymorphisms in the CNR1 gene [117,137,138].

The environment, both independently and in interaction with heritable factors, plays a relevant role in the onset of EDs and may influence gene expression via epigenetic mechanisms [139].

A possible transcriptional regulation of CNR1 gene, through DNA methylation of its promoter, was investigated in two animal models of AN (one behavioral and one genetic), in order to gain insight on players involved in AN onset and development [124].

More specifically, as an environmental model, it has been used the ABA model, through which rats are exposed to a restricted feeding schedule combined with physical activity, by giving them free access to a running wheel; a "combo" able to induce to a reduction in food intake, dramatic body weight loss and hyperactivity [140-142].

The major outcome of the above-mentioned study is that, among genes of the ECS, the expression of only CNR1 gene resulted to be altered in the ABA group and selectively in the HYP and in the NAc. Moreover, epigenetic analysis on the CNR1 gene promoter showed a consistent and significant increase of DNA methylation in the NAc; whereas, no changes of the epigenetic mark occurred at the earliest time-point (3 days induction) in the same area, nor in the HYP at neither time-points. Moreover, a significant correlation between body weight and both CNR1 expression and DNA methylation was reported. No changes were instead observed in the genetic model of AN, the anx/anx mice [143]. This let the authors to suggest that the selective molecular alterations reported in the ABA model were due to environmental cues (i.e., food restriction and physical activity), and not driven by a genetic predisposition. 
In this respect, we would like to point out that we recently analyzed the transcriptional regulation of CNR1 gene in a small population of subjects with restricted eating habits, mainly resembling AN feature [144]. Recruited subjects were females $(n=9)$ selected based on the age (18 to 65 years old, excluding pregnant women and people with known genetic mutations) and BMI (BMI $\geq 18.5-<25$ for normal weight subjects with restricted eating habits, BMI $<18.5-\geq 17$ for mild malnutrition, $\mathrm{BMI}<17-\geq 16$ moderate malnutrition, BMI $<16-\geq 15$ severe malnutrition and BMI $<15$ extreme malnutrition), with healthy subjects $(n=21)$ included as controls. Preliminary findings indicate that, in addition to food restriction, other environmental cues seem to be necessary to alter, in saliva, CNR1 gene DNA methylation patterns, that we analyzed by pyrosequencing as previously described [92] (see Figure 2A for details of the sequence under investigation). These additional environmental inputs include abnormally high levels of physical activity, previously experienced stressful events and/or dieting history. Among the $5 \mathrm{CpG}$ sites under study at CNR1 gene, we have observed the most pronounced methylation differences at CpG site 4 (Figure 2B) (unpublished data ref [144]). Moreover, we identified retinoid $X$ receptor alpha (RXR- $\alpha$ ) as the transcription factor (TF) that binds this CpG site. Retinoic acid receptors (RAR) form heterodimers with RXR exerting a broad range of biological effects. For instance, RARs are involved in $\mathrm{CB}_{1} \mathrm{R}$ up-regulation in both alcohol- and HFD-induced fatty liver and in mediating $\mathrm{CB}_{1} \mathrm{R}$ expression evoked by eCBs [145]. Moreover, the same $\mathrm{CpG}$ site 4 binds another TF, glucocorticoid receptor alpha $(\mathrm{GR} \alpha)$, well known for its implication in metabolic conditions of obesity and diabetes and psychiatric illnesses [146]. Agonistic actions on the GR promote fat deposition and central adiposity with adverse metabolic profile, including hyperglycemia, insulin resistance, dyslipidemia and hypertension, observed both in animal models and in human subjects $[147,148]$. Finally, a synthetic GC was shown to up-regulate peripheral CNR1 expression, suggesting it is involved in GR-regulated lipolysis making it an attractive drug target in type 2 diabetes and dyslipidemia [149].

Defects in the endocannabinoid signaling, mediated primarily by $\mathrm{CB}_{1} \mathrm{R}$, have been also implicated in development of binge eating disorder (BED), characterized by recurrent episodes of binge eating, with no compensatory behaviors to prevent weight gain, such as vomiting or laxative abuse [150]; therefore, obese individuals are the most commonly affected by $B E D$ [151]. $\mathrm{CB}_{1} \mathrm{R}$ antagonist/inverse agonist rimonabant has been demonstrated to decrease binge eating behavior in female rats by reducing the consumption of the HFD binged, with the accompanying significant body weight loss [152]. It has been also recently demonstrated that female rats under dietary-induced binge eating show a modified central eCB tone in several brain areas within the mesocorticolimbic system, which is the principal neural pathway that drives hedonic eating, as well as reduced $C_{1} R$ density in the prefrontal cortex, probably related to the development and maintenance of this behavior [153]. Moreover, $\mathrm{CB}_{1} \mathrm{R}$-dependent positive reinforcement appears responsible for maintenance of excessive food intake upon withdrawal [154]. With regards to genetic variants, specific allele has been associated with bingeing/purging $\mathrm{AN}$, but not restricting subtype of AN [115], while several polymorphisms in CNR1 gene as well as FAAH gene have been associated with addiction and binge-drinking [155-158]. Recently, the study of ECS components transcriptional regulation [159] in a rat model of binge-like eating showed altered levels of just FAAH gene in the HYP of binge-eating group. BED also has a complex multifactorial etiology, with both genetic and environmental factors implicated [160]. Evidence on the epigenetic of CNR1 gene in BED are scarce: one report showed a reduced DNA methylation in CNR1 gene promoter in the prefrontal cortex of eating addictedlike animals, correlated with an elevated expression of $\mathrm{CB}_{1} \mathrm{R}$ protein in the same brain region [161]. More recently, a crucial role of glutamatergic CNR1 gene has been proposed as part of the regulatory mechanisms of relevance in the loss of inhibitory control for palatable food seeking and consumption [162]. 


\section{A}

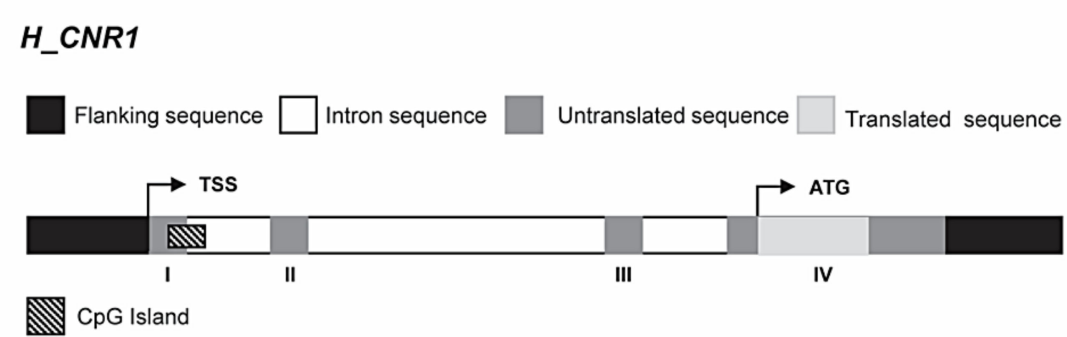

...GCAGAGCTCTCCGTAGTCAGTGGGGGATATTTCGTTCTAGCGGACAACCAGCCCCTG AGCTGGGCGAGAGGTGCCAAGGGAGCTTCTGTCCCGAGGACCAGGGGATGCGAAGGgt aagacctggcagagttg $\mathbf{C g}$ tttggaaatacttttc $\mathbf{C g}$ cctcc $\mathbf{C g} \operatorname{cccct} \mathbf{C g}$ ggtaCgaccagtgtggtccccaagtgtc cttcgtggagttcttattccgtgtgagcgaatcgtgcgtcggtgtttacttagctgtatggecccagcctgttaactgtgatctgttctactt ctggagatttctaccatttactatttattgaatgtgtgtgcacctggctctgtatgcactgatgtctgtttgtagaaaa...

B

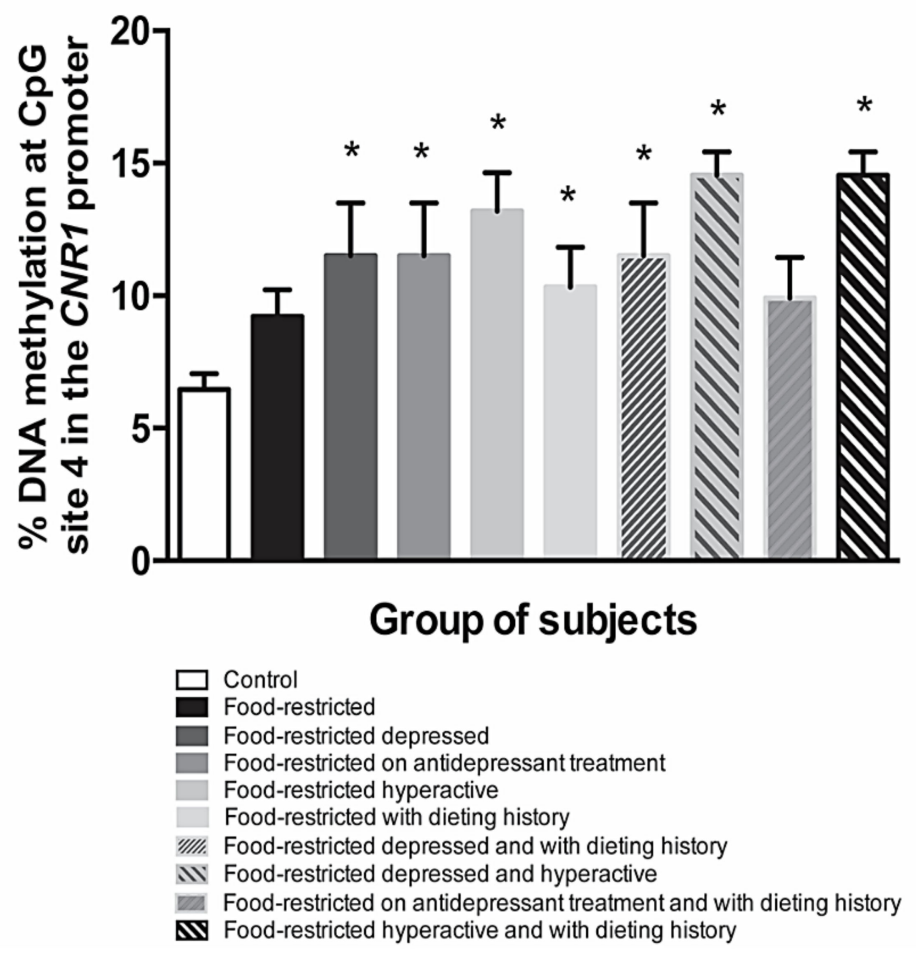

Figure 2. (A) Representation of human CNR1 gene and sequence of $\mathrm{CpG}$ islands (human GRcH38: crh 6:88165719-88165820) studied for DNA methylation. Flanking sequences are marked in black, UTRs in dark gray, coding regions in light gray, introns in white and CpG islands in lined pattern. Position of ATG, TSS and exons are also reported. Bold text indicates the CpG sites analyzed; framed CG indicates the CpG site number 4. (B) DNA methylation status at the CpG site number 4 in the sequence of the human CNR1 gene under study in food-restricted subjects stratified based on the co-occurrence of different environmental factors. The bars represent the mean of the $\%$ of DNA methylation \pm the SEM in the different subgroups. Significant differences are indicated as * $p<0.05$ vs. Control [144].

\section{Conclusions}

The ECS is a constitutive signaling system that plays a critical role in energy homeostasis by promoting consumption of palatable food, stimulating fat mass expansion and inhibiting energy expenditure and thermogenesis. Via $\mathrm{CB}_{1} \mathrm{R}$, eCBs modulate homeostatic and rewarding neural circuitries, and regulates consequently eating behaviors and energy balance, according to food availability: activation of eCB signaling is favorable when access to food is restricted, whereas it promotes obesity and metabolic diseases when food is abundant. Engagement of ECS occurs in conjunction with other metabolic signals, particu- 
larly leptin, that act synergistically through their specific neuronal pathways to maintain body energy homeostasis. We provided an overview of the role of CNR1 gene in EDs and obesity, in order to further stimulate the challenging idea that the modulation of CNR1 gene transcriptional regulation might represent a promising approach to prevent or to treat these pathologies, in addition to existing pharmacological interventions on $C_{1} R$ [103].

Author Contributions: Conceptualization: C.D. and M.P.; validation: C.D., C.C., and M.M.; resources, C.D., C.C.; writing—original draft preparation, C.D., E.Z., M.P.; writing—review and editing: C.C., M.M., M.V.M.D.B., E.M.D.B.; supervision, P.D.C.; funding acquisition, C.D. All authors have read and agreed to the published version of the manuscript.

Funding: This research was funded by Marie Skłodowska-Curie grant agreement no. 713714 (RepEat-H2020-MSCACOFUND-2015) and partially by a grant from the Italian Ministry of Education, University and Research (PRIN2015KP7T2Y) to C.C. Partial support by the EU-LAC (European LatinoAmerican Countries) Foundation under competitive grant EULAC16/T01-0132 to MM is also gratefully acknowledged. The EU-LAC Foundation had no role in the design or conduct of the study.

Institutional Review Board Statement: Not applicable.

Informed Consent Statement: Informed consent was obtained from all subjects involved in the preliminary data obtained that we here report.

Data Availability Statement: The data presented in this study reference [144] are available on request from the corresponding author. The data are not publicly available since they are part of an unpublished work.

Conflicts of Interest: The authors declare no conflict of interest.

$\begin{array}{ll}\text { Abbreviations } \\ \text { HYP } & \text { HYPothalamus } \\ \text { EDs } & \text { Eating Disorder } \\ \text { NAc } & \text { Nucleus Accumbens } \\ \text { ECS } & \text { Endocannabinoid System } \\ \text { CB } 1 \text { R } & \text { Type-1 Cannabinoid Receptor } \\ \text { CNR1 } & \text { Type-1 Cannabinoid Receptor gene } \\ \text { CNS } & \text { Central Nervous System } \\ \text { eCBs } & \text { endogenous Cannabinoids } \\ \text { FAAH } & \text { Fatty Acid Amide Hydrolase } \\ \text { 5'-UTR } & \text { 5'-Untranslated Region } \\ \text { CpG } & \text { Cytosine-phosphate-Guanine } \\ \text { TSS } & \text { Transcription Start Site } \\ \text { ATG } & \text { Translation start site } \\ \text { bp } & \text { base pairs } \\ \text { KO } & \text { Knock-Out } \\ \text { CB }{ }_{2} \text { R } & \text { Type-2 Cannabinoid Receptor } \\ \text { HFD } & \text { High Fat Diet } \\ \text { SNP } & \text { Single Nucleotide Polymorphism } \\ \text { BMI } & \text { Body Mass Index } \\ \text { DSM } & \text { Diagnostic and Statistical Manual of Mental Disorders } \\ \text { AN } & \text { Anorexia Nervosa } \\ \text { BN } & \text { Bulimia Nervosa } \\ \text { AAT } & \text { Adenine-Adenine-Thymine } \\ \text { ABA } & \text { Activity-Based Anorexia } \\ \text { RXR } & \text { Retinoid X Receptor } \\ \text { TF } & \text { Transcription Factor } \\ \text { RAR } & \text { Retinoic Acid Receptors } \\ \text { GR } & \text { Glucocorticoid Receptor } \\ \text { BED } & \text { Binge Eating Disorder } \\ & \end{array}$




\section{References}

1. Berthoud, H.-R. The neurobiology of food intake in an obesogenic environment. In Nutrition Society; Cambridge University Press (CUP): Cambridge, UK, 2012; Volume 71, pp. 478-487.

2. Johnson, A.W. Eating beyond metabolic need: How environmental cues influence feeding behavior. Trends Neurosci. 2013, 36, 101-109. [CrossRef]

3. Schneeberger, M.; Gomis, R.; Claret, M. Hypothalamic and brainstem neuronal circuits controlling homeostatic energy balance. J. Endocrinol. 2014, 220, T25-T46. [CrossRef]

4. Yeo, G.; Heisler, L.K. Unraveling the brain regulation of appetite: Lessons from genetics. Nat. Neurosci. 2012, 15, 1343-1349. [CrossRef] [PubMed]

5. Cifani, C.; Di Bonaventura, M.V.E.; Epucci, M.; Egiusepponi, M.E.; Eromano, A.; Francesco, A.E.; Emaccarrone, M.; D’’Addario, C. Regulation of hypothalamic neuropeptides gene expression in diet induced obesity resistant rats: Possible targets for obesity prediction? Front. Neurosci. 2015, 9, 187. [CrossRef] [PubMed]

6. Di Bonaventura, M.V.M.; Pucci, M.; Giusepponi, M.E.; Romano, A.; Lambertucci, C.; Volpini, R.; Di Bonaventura, E.M.; Gaetani, S.; Maccarrone, M.; D'Addario, C.; et al. Regulation of adenosine A2A receptor gene expression in a model of binge eating in the amygdaloid complex of female rats. J. Psychopharmacol. 2019, 33, 1550-1561. [CrossRef] [PubMed]

7. Pucci, M.; Di Bonaventura, M.V.M.; Giusepponi, M.E.; Romano, A.; Filaferro, M.; Maccarrone, M.; Ciccocioppo, R.; Cifani, C.; D'Addario, C. Epigenetic regulation of nociceptin/orphanin FQ and corticotropin-releasing factor system genes in frustration stress-induced binge-like palatable food consumption. Addict. Biol. 2015, 21, 1168-1185. [CrossRef]

8. Garfield, A.S.; Shah, B.P.; Burgess, C.R.; Li, M.M.; Li, C.; Steger, J.S.; Madara, J.C.; Campbell, J.N.; Kroeger, D.; Scammell, T.E.; et al. Dynamic GABAergic afferent modulation of AgRP neurons. Nat. Neurosci. 2016, 19, 1628-1635. [CrossRef]

9. Rossi, M.A.; Stuber, G.D. Overlapping Brain Circuits for Homeostatic and Hedonic Feeding. Cell Metab. 2018, 27, 42-56. [CrossRef]

10. Jager, G.; Witkamp, R.F. The endocannabinoid system and appetite: Relevance for food reward. Nutr. Res. Rev. 2014, 27, 172-185. [CrossRef]

11. Novelle, M.G.; Dieguez, C. Food Addiction and Binge Eating: Lessons Learned from Animal Models. Nutrients 2018, 10, 71. [CrossRef]

12. Blouet, C.; Schwartz, G.J. Hypothalamic nutrient sensing in the control of energy homeostasis. Behav. Brain Res. 2010, $209,1-12$. [CrossRef] [PubMed]

13. Coll, A.P.; Farooqi, I.S.; O'Rahilly, S. The Hormonal Control of Food Intake. Cell 2007, 129, 251-262. [CrossRef] [PubMed]

14. Dietrich, M.O.; Horvath, T.L. Hypothalamic control of energy balance: Insights into the role of synaptic plasticity. Trends Neurosci. 2013, 36, 65-73. [CrossRef] [PubMed]

15. Volkow, N.D.; Wang, G.-J.; Baler, R.D. Reward, dopamine and the control of food intake: Implications for obesity. Trends Cogn. Sci. 2011, 15, 37-46. [CrossRef] [PubMed]

16. Belgardt, B.F.; Okamura, T.; Brüning, J.C. Hormone and glucose signalling in POMC and AgRP neurons. J. Physiol. 2009, 587, 5305-5314. [CrossRef] [PubMed]

17. Goldstone, A.P. The hypothalamus, hormones, and hunger: Alterations in human obesity and illness. Neural Regen. 2006, 153, 57-73. [CrossRef]

18. Wang, H.; Astarita, G.; Taussig, M.D.; Bharadwaj, K.G.; DiPatrizio, N.V.; Nave, K.-A.; Piomelli, D.; Goldberg, I.J.; Eckel, R.H. Deficiency of Lipoprotein Lipase in Neurons Modifies the Regulation of Energy Balance and Leads to Obesity. Cell Metab. 2011, 13, 105-113. [CrossRef]

19. Land, B.B.; Narayanan, N.S.; Liu, R.-J.; Gianessi, C.A.; Brayton, C.E.; Grimaldi, D.M.; Sarhan, M.; Guarnieri, D.J.; Deisseroth, K.; Aghajanian, G.K.; et al. Medial prefrontal D1 dopamine neurons control food intake. Nat. Neurosci. 2014, 17, 248-253. [CrossRef]

20. Petrovich, G.D.; Holland, P.C.; Gallagher, M. Amygdalar and Prefrontal Pathways to the Lateral Hypothalamus Are Activated by a Learned Cue That Stimulates Eating. J. Neurosci. 2005, 25, 8295-8302. [CrossRef]

21. Volkow, N.D.; Fowler, J.; Wang, G.; Baler, R.; Telang, F. Imaging dopamine's role in drug abuse and addiction. Neuropharmacology 2009, 56, 3-8. [CrossRef]

22. Lutter, M.; Nestler, E.J. Homeostatic and Hedonic Signals Interact in the Regulation of Food Intake. J. Nutr. 2009, 139, 629-632. [CrossRef] [PubMed]

23. Volkow, N.D.; Wang, G.-J.; Tomasi, D.; Baler, R.D. Obesity and addiction: Neurobiological overlaps. Obes. Rev. Off. J. Int. Assoc. Study Obes. 2013, 14, 2-18. [CrossRef] [PubMed]

24. D’Addario, C.; Di Bonaventura, M.M.; Pucci, M.; Romano, A.; Gaetani, S.; Ciccocioppo, R.; Cifani, C.; Maccarrone, M. Endocannabinoid signaling and food addiction. Neurosci. Biobehav. Rev. 2014, 47, 203-224. [CrossRef] [PubMed]

25. Coccurello, R.; Maccarrone, M. Hedonic Eating and the "Delicious Circle": From Lipid-Derived Mediators to Brain Dopamine and Back. Front. Neurosci. 2018, 12, 271. [CrossRef]

26. Di Marzo, V.; Goparaju, S.K.; Wang, L.; Liu, J.; Bátkai, S.; Járai, Z.; Fezza, F.; Miura, G.I.; Palmiter, R.D.; Sugiura, T.; et al. Leptin-regulated endocannabinoids are involved in maintaining food intake. Nat. Cell Biol. 2001, 410, 822-825. [CrossRef]

27. Berry, E.M.; Mechoulam, R. Tetrahydrocannabinol and endocannabinoids in feeding and appetite. Pharmacol. Ther. 2002, 95, 185-190. [CrossRef] 
28. Pi-Sunyer, X.; Aronne, L.J.; Heshmati, H.M.; Devin, J.; Rosenstock, J.; for the RIO-North America Study Group. Effect of Rimonabant, a Cannabinoid-1 Receptor Blocker, on Weight and Cardiometabolic Risk Factors in Overweight or Obese Patients. JAMA 2006, 295, 761-775. [CrossRef]

29. Engeli, S. Dysregulation of the Endocannabinoid System in Obesity. J. Neuroendocrinol. 2008, 20, 110-115. [CrossRef]

30. Mazier, W.; Saucisse, N.; Gatta-Cherifi, B.; Cota, D. The Endocannabinoid System: Pivotal Orchestrator of Obesity and Metabolic Disease. Trends Endocrinol. Metab. 2015, 26, 524-537. [CrossRef]

31. Zou, S.; Somvanshi, R.K.; Paik, S.; Kumar, U. Colocalization of Cannabinoid Receptor 1 with Somatostatin and Neuronal Nitric Oxide Synthase in Rat Brain Hypothalamus. J. Mol. Neurosci. 2014, 55, 480-491. [CrossRef]

32. Moldrich, G.; Wenger, T. Localization of the CB1 cannabinoid receptor in the rat brain. An immunohistochemical study. Peptides 2000, 21, 1735-1742. [CrossRef]

33. Bellocchio, L.; Cervino, C.; Pasquali, R.; Pagotto, U. The Endocannabinoid System and Energy Metabolism. J. Neuroendocrinol. 2008, 20, 850-857. [CrossRef] [PubMed]

34. Di Marzo, V.; Matias, I. Endocannabinoid control of food intake and energy balance. Nat. Neurosci. 2005, 8, 585-589. [CrossRef] [PubMed]

35. Hillard, C.J.; Beatka, M.; Sarvaideo, J. Endocannabinoid Signaling and the Hypothalamic-Pituitary-Adrenal Axis. Compr. Physiol. 2016, 7, 1-15. [CrossRef]

36. Silvestri, C.; Di Marzo, V. The Endocannabinoid System in Energy Homeostasis and the Etiopathology of Metabolic Disorders. Cell Metab. 2013, 17, 475-490. [CrossRef]

37. Melis, T.; Succu, S.; Sanna, F.; Boi, A.; Argiolas, A.; Melis, M.R. The cannabinoid antagonist SR 141716A (Rimonabant) reduces the increase of extra-cellular dopamine release in the rat nucleus accumbens induced by a novel high palatable food. Neurosci. Lett. 2007, 419, 231-235. [CrossRef]

38. DiPatrizio, N.V.; Simansky, K.J. Activating Parabrachial Cannabinoid CB1 Receptors Selectively Stimulates Feeding of Palatable Foods in Rats. J. Neurosci. 2008, 28, 9702-9709. [CrossRef]

39. Seagard, J.L.; Dean, C.; Patel, S.; Rademacher, D.J.; Hopp, F.A.; Schmeling, W.T.; Hillard, C.J. Anandamide content and interaction of endocannabinoid/GABA modulatory effects in the NTS on baroreflex-evoked sympathoinhibition. Am. J. Physiol. Circ. Physiol. 2004, 286, H992-H1000. [CrossRef]

40. Derbenev, A.V.; Stuart, T.C.; Smith, B.N. Cannabinoids suppress synaptic input to neurones of the rat dorsal motor nucleus of the vagus nerve. J. Physiol. 2004, 559, 923-938. [CrossRef]

41. Cota, D.; Genghini, S.; Pasquali, R.; Pagotto, U. Antagonizing the cannabinoid receptor Type 1: A dual way to fight obesity. J. Endocrinol. Investig. 2003, 26, 1041-1044. [CrossRef]

42. Williams, C.M.; Kirkham, T.C. Anandamide induces overeating: Mediation by central cannabinoid (CB1) receptors. Psychopharmacology 1999, 143, 315-317. [CrossRef] [PubMed]

43. Lau, B.K.; Cota, D.; Cristino, L.; Borgland, S.L. Endocannabinoid modulation of homeostatic and non-homeostatic feeding circuits Neuropharmacology 2017, 124, 38-51. [CrossRef] [PubMed]

44. Ravula, A.; Chandasana, H.; Setlow, B.; Febo, M.; Bruijnzeel, A.W.; Derendorf, H. Simultaneous quantification of cannabinoids tetrahydrocannabinol, cannabidiol and CB1 receptor antagonist in rat plasma: An application to characterize pharmacokinetics after passive cannabis smoke inhalation and co-administration of rimonabant. J. Pharm. Biomed. Anal. 2018, 160, 119-125. [CrossRef] [PubMed]

45. Sam, A.H.; Salem, V.; Ghatei, M.A. Rimonabant: From RIO to Ban. J. Obes. 2011, 2011, 1-4. [CrossRef]

46. Herkenham, M.; Lynn, A.B.; Little, M.D.; Johnson, M.R.; Melvin, L.S.; De Costa, B.R.; Rice, K.C. Cannabinoid receptor localization in brain. Proc. Natl. Acad. Sci. USA 1990, 87, 1932-1936. [CrossRef]

47. Hryhorowicz, S.; Kaczmarek-Ryś, M.; Andrzejewska, A.; Staszak, K.; Korcz, A.; Słomski, R. Allosteric Modulation of Cannabinoid Receptor 1-Current Challenges and Future Opportunities. Int. J. Mol. Sci. 2019, 20, 5874. [CrossRef]

48. Di Marzo, V.; Stella, N.; Zimmer, A. Endocannabinoid signalling and the deteriorating brain. Nat. Rev. Neurosci. 2015, 16, 30-42. [CrossRef]

49. DiPatrizio, N.V.; Piomelli, D. Intestinal lipid-derived signals that sense dietary fat. J. Clin. Investig. 2015, 125, 891-898. [CrossRef]

50. Maccarrone, M.; Bab, I.; Bíró, T.; Cabral, G.A.; Dey, S.K.; Di Marzo, V.; Konje, J.C.; Kunos, G.; Mechoulam, R.; Pacher, P.; et al. Endocannabinoid signaling at the periphery: 50 years after THC. Trends Pharmacol. Sci. 2015, 36, 277-296. [CrossRef]

51. Begg, M.; Pacher, P.; Bátkai, S.; Osei-Hyiaman, D.; Offertáler, L.; Mo, F.M.; Liu, J.; Kunos, G. Evidence for novel cannabinoid receptors. Pharmacol. Ther. 2005, 106, 133-145. [CrossRef]

52. Ryberg, E.; Larsson, N.; Sjögren, S.; Hjorth, S.; Hermansson, N.-O.; Leonova, J.; Elebring, T.; Nilsson, K.; Drmota, T.; Greasley, P.J. The orphan receptor GPR55 is a novel cannabinoid receptor. Br. J. Pharmacol. 2007, 152, 1092-1101. [CrossRef] [PubMed]

53. Matsuda, L.A.; Lolait, S.J.; Brownstein, M.J.; Young, A.C.; Bonner, T.I. Structure of a cannabinoid receptor and functional expression of the cloned cDNA. Nat. Cell Biol. 1990, 346, 561-564. [CrossRef] [PubMed]

54. Ruehle, S.; Wager-Miller, J.; Straiker, A.; Farnsworth, J.; Murphy, M.N.; Loch, S.; Monory, K.; Mackie, K.; Lutz, B. Discovery and characterization of two novel CB1 receptor splice variants with modified N-termini in mouse. J. Neurochem. 2017, 142, 521-533. [CrossRef] [PubMed]

55. Bonner, T. Molecular biology of cannabinoid receptors. J. Neuroimmunol. 1996, 69, 15-17. 
56. McCaw, E.A.; Hu, H.; Gomez, G.T.; Hebb, A.L.O.; Kelly, M.E.M.; Denovan-Wright, E.M. Structure, expression and regulation of the cannabinoid receptor gene (CB1) in Huntington's disease transgenic mice. JBIC J. Biol. Inorg. Chem. 2004, 271, 4909-4920. [CrossRef] [PubMed]

57. Zhang, P.-W.; Ishiguro, H.; Ohtsuki, T.; Hess, J.; Carillo, F.; Walther, D.; Onaivi, E.S.; Arinami, T.; Uhl, G.R. Human cannabinoid receptor 1:5' exons, candidate regulatory regions, polymorphisms, haplotypes and association with polysubstance abuse. Mol. Psychiatry 2004, 9, 916-931. [CrossRef] [PubMed]

58. Miller, L.K.; Devi, L.A. The Highs and Lows of Cannabinoid Receptor Expression in Disease: Mechanisms and Their Therapeutic Implications. Pharmacol. Rev. 2011, 63, 461-470. [CrossRef]

59. Shire, D.; Calandra, B.; Delpech, M.; Dumont, X.; Kaghad, M.; Le Fur, G.; Caput, D.; Ferrara, P. Structural Features of the Central Cannabinoid CB1 Receptor Involved in the Binding of the Specific CB1 Antagonist SR 141716A. J. Biol. Chem. 1996, 271, 6941-6946. [CrossRef]

60. Gustafsson, K.; Wang, X.; Severa, D.; Eriksson, M.; Kimby, E.; Merup, M.; Christensson, B.; Flygare, J.; Sander, B. Expression of cannabinoid receptors type 1 and type 2 in non-Hodgkin lymphoma: Growth inhibition by receptor activation. Int. J. Cancer 2008, 123, 1025-1033. [CrossRef]

61. Palermo, F.A.; Angelini, M.; Cottone, E.; Virgili, M.; Franzoni, M.F.; Mosconi, G.; Polzonetti-Magni, A.M. Involvement of Endocannabinoid CB1 Receptor in the Modulation of Stress Responses Related to Xenoestrogen Exposure. Ann. N. Y. Acad. Sci. 2009, 1163, 504-507. [CrossRef]

62. Ryberg, E.; Vu, H.K.; Larsson, N.; Groblewski, T.; Hjorth, S.; Elebring, T.; Sjögren, S.; Greasley, P.J. Identification and characterisation of a novel splice variant of the human CB1 receptor. FEBS Lett. 2004, 579, 259-264. [CrossRef] [PubMed]

63. Agrawal, A.; Wetherill, L.; Dick, D.M.; Xuei, X.; Hinrichs, A.; Hesselbrock, V.; Kramer, J.; Nurnberger, J.I., Jr.; Schuckit, M.; Bierut, L.J.; et al. Evidence for association between polymorphisms in the cannabinoid receptor 1 (CNR1) gene and cannabis dependence. Am. J. Med. Genet. Part B Neuropsychiatr. Genet. 2009, 150B, 736-740. [CrossRef] [PubMed]

64. Feng, Q.; Vickers, K.C.; Anderson, M.; Levin, M.; Chen, W.; Harrison, D.G.; Wilke, R.A. A common functional promoter variant links CNR1 gene expression to HDL cholesterol level. Nat. Commun. 2013, 4, 1-7. [CrossRef] [PubMed]

65. Gadzicki, D.; Müller-Vahl, K.; Stuhrmann, M. A frequent polymorphism in the coding exon of the human cannabinoid receptor (CNR1) gene. Mol. Cell. Probes 1999, 13, 321-323. [CrossRef] [PubMed]

66. Hartman, C.A.; Hopfer, C.J.; Haberstick, B.; Rhee, S.H.; Crowley, T.J.; Corley, R.P.; Hewitt, J.K.; Ehringer, M.A. The association between cannabinoid receptor 1 gene (CNR1) and cannabis dependence symptoms in adolescents and young adults. Drug Alcohol Depend. 2009, 104, 11-16. [CrossRef]

67. Ruiz-Contreras, A.E.; Román-López, T.V.; Caballero-Sánchez, U.; Rosas-Escobar, C.B.; Ortega-Mora, E.I.; Barrera-Tlapa, M.A.; Romero-Hidalgo, S.; Carrillo-Sánchez, K.; Hernández-Morales, S.; Vadillo-Ortega, F.; et al. Because difficulty is not the same for everyone: The impact of complexity in working memory is associated with cannabinoid 1 receptor genetic variation in young adults. Memory 2016, 25, 335-343. [CrossRef]

68. González-Mariscal, I.; Krzysik-Walker, S.M.; Doyle, M.E.; Liu, Q.-R.; Cimbro, R.; Calvo, S.S.-C.; Ghosh, S.; Ciesla, L.; Moaddel, R.; Carlson, O.D.; et al. Human CB1 Receptor Isoforms, present in Hepatocytes and $\beta$-cells, are Involved in Regulating Metabolism. Sci. Rep. 2016, 6, 33302. [CrossRef]

69. Shire, D.; Carillon, C.; Kaghad, M.; Calandra, B.; Rinaldi-Carmona, M.; Le Fur, G.; Caput, D.; Ferrara, P. An Amino-terminal Variant of the Central Cannabinoid Receptor Resulting from Alternative Splicing. J. Biol. Chem. 1995, 270, 3726-3731. [CrossRef]

70. Elphick, M.R. The evolution and comparative neurobiology of endocannabinoid signalling. Philos. Trans. R. Soc. Lond. Ser. B Biol. Sci. 2012, 367, 3201-3215. [CrossRef]

71. Marsicano, G.; Lutz, B. Expression of the cannabinoid receptor CB1 in distinct neuronal subpopulations in the adult mouse forebrain. Eur. J. Neurosci. 1999, 11, 4213-4225. [CrossRef]

72. Han, J.; Kesner, P.; Metna-Laurent, M.; Duan, T.; Xu, L.; Georges, F.; Koehl, M.; Abrous, D.N.; Mendizabal-Zubiaga, J.; Grandes, P.; et al. Acute Cannabinoids Impair Working Memory through Astroglial CB1 Receptor Modulation of Hippocampal LTD. Cell 2012, 148, 1039-1050. [CrossRef] [PubMed]

73. Stella, N. Cannabinoid and cannabinoid-like receptors in microglia, astrocytes, and astrocytomas. Glia 2010, 58, 1017-1030. [CrossRef] [PubMed]

74. Glass, M.; Faull, R.; Dragunow, M. Cannabinoid receptors in the human brain: A detailed anatomical and quantitative autoradiographic study in the fetal, neonatal and adult human brain. Neuroscience 1997, 77, 299-318. [CrossRef]

75. Kruk-Slomka, M.; Dzik, A.; Budzynska, B.; Biala, G. Endocannabinoid System: The Direct and Indirect Involvement in the Memory and Learning Processes-A Short Review. Mol. Neurobiol. 2017, 54, 8332-8347. [CrossRef] [PubMed]

76. Mackie, K. Distribution of Cannabinoid Receptors in the Central and Peripheral Nervous System. Handb. Exp. Pharmacol. 2005, 299-325. [CrossRef]

77. Tsou, K.; Brown, S.; Sañudo-Peña, M.; Mackie, K.; Walker, J. Immunohistochemical distribution of cannabinoid CB1 receptors in the rat central nervous system. Neuroscience 1998, 83, 393-411. [CrossRef]

78. Klein, T.W.; Newton, C.; Larsen, K.; Lu, L.; Perkins, I.; Nong, L.; Friedman, H. The cannabinoid system and immune modulation. J. Leukoc. Biol. 2003, 74, 486-496. [CrossRef] 
79. Maccarrone, M.; De Petrocellis, L.; Bari, M.; Fezza, F.; Salvati, S.; Di Marzo, V.; Finazzi-Agrò, A. Lipopolysaccharide Downregulates Fatty Acid Amide Hydrolase Expression and Increases Anandamide Levels in Human Peripheral Lymphocytes. Arch. Biochem. Biophys. 2001, 393, 321-328. [CrossRef]

80. Nong, L.; Newton, C.; Friedman, H.; Klein, T.W. CB1 and CB2 Receptor mRNA Expression in Human Peripheral Blood Mononuclear Cells (PBMC) from Various Donor Types. Adv. Exp. Med. Biol. 2001, 493, 229-233. [CrossRef]

81. Spoto, B.; Fezza, F.; Parlongo, G.; Battista, N.; Sgro', E.; Gasperi, V.; Zoccali, C.; Maccarrone, M. Human adipose tissue binds and metabolizes the endocannabinoids anandamide and 2-arachidonoylglycerol. Biochimie 2006, 88, 1889-1897. [CrossRef]

82. Pereira, M.J.; Palming, J.; Svensson, M.K.; Rizell, M.; Dalenbäck, J.; Hammar, M.; Fall, T.; Sidibeh, C.O.; Svensson, P.-A.; Eriksson, J.W. FKBP5 expression in human adipose tissue increases following dexamethasone exposure and is associated with insulin resistance. Metabolism 2014, 63, 1198-1208. [CrossRef] [PubMed]

83. Timper, K.; Brüning, J.C. Hypothalamic circuits regulating appetite and energy homeostasis: Pathways to obesity. Dis. Models Mech. 2017, 10, 679-689. [CrossRef] [PubMed]

84. Kola, B.; Farkas, I.; Christ-Crain, M.; Wittmann, G.; Lolli, F.; Amin, F.; Harvey-White, J.; Liposits, Z.; Kunos, G.; Grossman, A.B.; et al. The Orexigenic Effect of Ghrelin Is Mediated through Central Activation of the Endogenous Cannabinoid System. PLoS ONE 2008, 3, e1797. [CrossRef] [PubMed]

85. Cota, D.; Marsicano, G.; Tschöp, M.; Grübler, Y.; Flachskamm, C.; Schubert, M.; Auer, D.; Yassouridis, A.; Thöne-Reineke, C.; Ortmann, S.; et al. The endogenous cannabinoid system affects energy balance via central orexigenic drive and peripheral lipogenesis. J. Clin. Investig. 2003, 112, 423-431. [CrossRef] [PubMed]

86. Cardinal, P.; Bellocchio, L.; Clark, S.; Cannich, A.; Klugmann, M.; Lutz, B.; Marsicano, G.; Cota, D. Hypothalamic CB1 Cannabinoid Receptors Regulate Energy Balance in Mice. Endocrinology 2012, 153, 4136-4143. [CrossRef] [PubMed]

87. De Azua, I.R.; Mancini, G.; Srivastava, R.K.; Rey, A.A.; Cardinal, P.; Tedesco, L.; Zingaretti, C.M.; Sassmann, A.; Quarta, C.; Schwitter, C.; et al. Adipocyte cannabinoid receptor CB1 regulates energy homeostasis and alternatively activated macrophages. J. Clin. Investig. 2017, 127, 4148-4162. [CrossRef]

88. Quarta, C.; Bellocchio, L.; Mancini, G.; Mazza, R.; Cervino, C.; Braulke, L.J.; Fekete, C.; Latorre, R.; Nanni, C.; Bucci, M.; et al. CB1 Signaling in Forebrain and Sympathetic Neurons Is a Key Determinant of Endocannabinoid Actions on Energy Balance. Cell Metab. 2010, 11, 273-285. [CrossRef]

89. Fride, E.; Foox, A.; Rosenberg, E.; Faigenboim, M.; Cohen, V.; Barda, L.; Blau, H.; Mechoulam, R. Milk intake and survival in newborn cannabinoid CB1 receptor knockout mice: Evidence for a "CB3" receptor. Eur. J. Pharmacol. 2003, 461, 27-34. [CrossRef]

90. Fride, E.; Ginzburg, Y.; Breuer, A.; Bisogno, T.; Di Marzo, V.; Mechoulam, R. Critical role of the endogenous cannabinoid system in mouse pup suckling and growth. Eur. J. Pharmacol. 2001, 419, 207-214. [CrossRef]

91. Gamelin, F.-X.; Aucouturier, J.; Iannotti, F.A.; Piscitelli, F.; Mazzarella, E.; Aveta, T.; Leriche, M.; Dupont, E.; Cieniewski-Bernard, C.; Montel, V.; et al. Effects of chronic exercise on the endocannabinoid system in Wistar rats with high-fat diet-induced obesity. J. Physiol. Biochem. 2016, 72, 183-199. [CrossRef]

92. Pucci, M.; Di Bonaventura, M.V.M.; Vezzoli, V.; Zaplatic, E.; Massimini, M.; Mai, S.; Sartorio, A.; Scacchi, M.; Persani, L.; Maccarrone, M.; et al. Preclinical and Clinical Evidence for a Distinct Regulation of Mu Opioid and Type 1 Cannabinoid Receptor Genes Expression in Obesity. Front. Genet. 2019, 10, 523. [CrossRef] [PubMed]

93. Ramírez-López, M.T.; Arco, R.; Decara, J.; Vázquez, M.; Rivera, P.; Blanco, R.N.; Alén, F.; De Heras, R.G.; Suárez, J.; De Fonseca, F.R. Long-Term Effects of Prenatal Exposure to Undernutrition on Cannabinoid Receptor-Related Behaviors: Sex and Tissue-Specific Alterations in the mRNA Expression of Cannabinoid Receptors and Lipid Metabolic Regulators. Front. Behav. Neurosci. 2016, 10, 241. [CrossRef] [PubMed]

94. Harrold, J.A.; Elliott, J.C.; King, P.J.; Widdowson, P.S.; Williams, G. Down-regulation of cannabinoid-1 (CB-1) receptors in specific extrahypothalamic regions of rats with dietary obesity: A role for endogenous cannabinoids in driving appetite for palatable food? Brain Res. 2002, 952, 232-238. [CrossRef]

95. South, T.; Huang, X.-F. Temporal and Site-Specific Brain Alterations in CB1 Receptor Binding in High Fat Diet-Induced Obesity in C57Bl/6 Mice. J. Neuroendocr. 2008, 20, 1288-1294. [CrossRef]

96. Almeida, M.M.; Dias-Rocha, C.P.; Reis-Gomes, C.F.; Wang, H.; Atella, G.C.; Cordeiro, A.; Pazos-Moura, C.C.; Joss-Moore, L.A.; Trevenzoli, I.H. Maternal high-fat diet impairs leptin signaling and up-regulates type-1 cannabinoid receptor with sex-specific epigenetic changes in the hypothalamus of newborn rats. Psychoneuroendocrinology 2019, 103, 306-315. [CrossRef]

97. Van Djik, S.; Tellam, R.L.; Morrison, J.L.; Mühlhäusler, B.S.; Molloy, P. Recent developments on the role of epigenetics in obesity and metabolic disease. Clin. Epigenetics 2015, 7, 1-13. [CrossRef]

98. Baye, T.M.; Zhang, Y.; Smith, E.; Hillard, C.J.; Gunnell, J.; Myklebust, J.B.; James, R.; Kissebah, A.H.; Olivier, M.; Wilke, R.A. Genetic variation in cannabinoid receptor 1 (CNR1) is associated with derangements in lipid homeostasis, independent of body mass index. Pharmacogenomics 2008, 9, 1647-1656. [CrossRef]

99. Li, N.; Cao, T.; Wu, X.; Tang, M.; Xiang, D.; Cai, H. Progress in Genetic Polymorphisms Related to Lipid Disturbances Induced by Atypical Antipsychotic Drugs. Front. Pharmacol. 2020, 10, 1669. [CrossRef]

100. Caruso, M.G.; Gazzerro, P.; Notarnicola, M.; Cisternino, A.M.; Guerra, V.; Misciagna, G.; Laezza, C.; Bifulco, M. Cannabinoid Type 1 Receptor Gene Polymorphism and Macronutrient Intake. J. Nutr. Nutr. 2012, 5, 305-313. [CrossRef]

101. De Luis, D.A.; Sagrado, M.G.; Aller, R.; Izaola, O.; Conde, R. Relation of G1359A polymorphism of the cannabinoid receptor (CB1) gene with metabolic syndrome by ATP III classification. Diabetes/Metab. Res. Rev. 2011, 27, 506-511. [CrossRef] 
102. Jaeger, J.P.; Mattevi, V.S.; Callegari-Jacques, S.M.; Hutz, M.H. Cannabinoid Type-1 Receptor Gene Polymorphisms Are Associated with Central Obesity in a Southern Brazilian Population. Dis. Markers 2008, 25, 67-74. [CrossRef] [PubMed]

103. Maccarrone, M.; Gasperi, V.; Catani, M.V.; Diep, T.A.; Dainese, E.; Hansen, H.S.; Avigliano, L. The Endocannabinoid System and Its Relevance for Nutrition. Annu. Rev. Nutr. 2010, 30, 423-440. [CrossRef] [PubMed]

104. Russo, P.; Strazzullo, P.; Cappuccio, F.P.; Tregouet, D.A.; Lauria, F.; Loguercio, M.; Barba, G.; Versiero, M.; Siani, A. Genetic Variations at the Endocannabinoid Type 1 Receptor Gene (CNR1) Are Associated with Obesity Phenotypes in Men. J. Clin. Endocrinol. Metab. 2007, 92, 2382-2386. [CrossRef] [PubMed]

105. Schleinitz, R.; Carmienke, S.; Böttcher, Y.; Tönjes, A.; Berndt, J.; Klöting, N.; Enigk, B.; Müller, I.; Dietrich, K.; Breitfeld, J.; et al. Role of genetic variation in the cannabinoid type 1 receptor gene (CNR1) in the pathophysiology of human obesity. Pharmacogenomics 2010, 11, 693-702. [CrossRef]

106. Zhuang, M.; Yang, Y.; Cao, F.; Lu, M.; Wang, X.; Zhang, J.; Chen, X.; Cheng, P.; Zhang, N.; Ye, W.; et al. Associations of variants of CNR1 with obesity and obesity-related traits in Chinese women. Gene 2012, 495, 194-198. [CrossRef]

107. Sadeghian, M.; Rahmani, S.; Mansoori, A. G1359A Variant of the Cannabinoid Receptor Gene (rs1049353) and Obesity-Related Traits and Related Endophenotypes: A Meta-Analysis. Ann. Nutr. Metab. 2018, 73, 76-85. [CrossRef]

108. Peeters, A.; Beckers, S.; Mertens, I.; Van Hul, W.; Van Gaal, L. The G1422A variant of the cannabinoid receptor gene (CNR1) is associated with abdominal adiposity in obese men. Endocrine 2007, 31, 138-141. [CrossRef]

109. Gazzerro, P.; Caruso, M.G.; Notarnicola, M.; Misciagna, G.; Guerra, V.; Laezza, C.; Bifulco, M. Association between cannabinoid type-1 receptor polymorphism and body mass index in a southern Italian population. Int. J. Obes. 2006, 31, 908-912. [CrossRef]

110. Frost, M.; Nielsen, T.L.; Wraae, K.; Hagen, C.; Piters, E.; Beckers, S.; De Freitas, F.; Brixen, K.; Van Hul, W.; Andersen, M.S. Polymorphisms in the endocannabinoid receptor 1 in relation to fat mass distribution. Eur. J. Endocrinol. 2010, 163, 407-412. [CrossRef]

111. Kvaløy, K.; Holmen, J.; Hveem, K.; Holmen, T.L. Genetic Effects on Longitudinal Changes from Healthy to Adverse Weight and Metabolic Status-The HUNT Study. PLoS ONE 2015, 10, e0139632. [CrossRef]

112. De Luis, D.A.; Pacheco, D.; Aller, R.; Sagrado, M.G.; Conde, R.; Izaola, O.; Cuellar, L.; Terroba, M.C.; Martin, T.; Ventosa, M. G 1359A polymorphism of the cannabinoid receptor gene (CNR1) and clinical results of biliopancreatic diversion. Eur. Rev. Med. Pharmacol. Sci. 2010, 14, 197-201. [PubMed]

113. Łaczmański, Ł.; Milewicz, A.; Dunajska, K.; Jędrzejczuk, D.; Pawlak, M.; Lwow, F. Endocannabinoid type 1 receptor gene (CNR1) polymorphisms (rs806381, rs10485170, rs6454674, rs2023239) and cardiovascular risk factors in postmenopausal women. Gynecol. Endocrinol. 2011, 27, 1023-1027. [CrossRef] [PubMed]

114. Müller, T.D.; Reichwald, K.; Brönner, G.; Kirschner, J.; Nguyen, T.T.; Scherag, A.; Herzog, W.; Herpertz-Dahlmann, B.; Lichtner, P.; Meitinger, T.; et al. Lack of association of genetic variants in genes of the endocannabinoid system with anorexia nervosa. Child Adolesc. Psychiatry Ment. Health 2008, 2, 33. [CrossRef] [PubMed]

115. American Psychiatric Association. Diagnostic and Statistical Manual of Mental Disorders: DSM-5; American Psychiatric Association: Arlington, VA, USA, 2013.

116. Monteleone, P.; Bifulco, M.; Di Filippo, C.; Gazzerro, P.; Canestrelli, B.; Proto, M.C.; Di Genio, M.; Grimaldi, C.; Maj, M. Association of CNR1 and FAAH endocannabinoid gene polymorphisms with anorexia nervosa and bulimia nervosa: Evidence for synergistic effects. Genes Brain Behav. 2009, 8, 728-732. [CrossRef]

117. Domschke, K.; Dannlowski, U.; Ohrmann, P.; Lawford, B.R.; Bauer, J.; Kugel, H.; Heindel, W.; Young, R.; Morris, P.; Arolt, V.; et al. Cannabinoid receptor 1 (CNR1) gene: Impact on antidepressant treatment response and emotion processing in Major Depression. Eur. Neuropsychopharmacol. 2008, 18, 751-759. [CrossRef]

118. Li, T.; Liu, X.; Zhu, Z.H.; Zhao, J.; Hu, X.; Ball, D.M.; Sham, P.C.; Collier, D.A. No association between (AAT)n repeats in the cannabinoid receptor gene (CNR1) and heroin abuse in a Chinese population. Mol. Psychiatry 2000, 5, 128-130. [CrossRef]

119. Siegfried, Z.; Kanyas, K.; Latzer, Y.; Karni, O.; Bloch, M.; Lerer, B.; Berry, E. Association study of cannabinoid receptor gene (CNR1) alleles and anorexia nervosa: Differences between restricting and bingeing/purging subtypes. Am. J. Med. Genet. 2004, 125B, 126-130. [CrossRef]

120. Trillou, C.R.; Delgorge, C.; Menet, C.; Arnone, M.; Soubrié, P. CB1 cannabinoid receptor knockout in mice leads to leanness, resistance to diet-induced obesity and enhanced leptin sensitivity. Int. J. Obes. 2004, 28, 640-648. [CrossRef]

121. Jbilo, O.; Trillou, C.R.; Arnone, M.; Buisson, I.; Bribes, E.; Péleraux, A.; Pénarier, G.; Soubrié, P.; Le Fur, G.; Galiègue, S.; et al. The $\mathrm{CB} 1$ receptor antagonist rimonabant reverses the diet-induced obesity phenotype through the regulation of lipolysis and energy balance. FASEB J. 2005, 19, 1567-1569. [CrossRef]

122. Nogueiras, R.; López, M.; Diéguez, C. Regulation of lipid metabolism by energy availability: A role for the central nervous system. Obes. Rev. 2010, 11, 185-201. [CrossRef]

123. Collu, R.; Scherma, M.; Piscitelli, F.; Giunti, E.; Satta, V.; Castelli, M.P.; Verde, R.; Fratta, W.; Bisogno, T.; Fadda, P. Impaired brain endocannabinoid tone in the activity-based model of anorexia nervosa. Int. J. Eat. Disord. 2019, 52, 1251-1262. [CrossRef] [PubMed]

124. D'Addario, C.; Ms, E.Z.; Giunti, E.; Pucci, M.; Di Bonaventura, M.V.M.; Scherma, M.; Dainese, E.; Maccarrone, M.; Nilsson, I.A.K.; Cifani, C.; et al. Epigenetic regulation of the cannabinoid receptor CB1 in an activity-based rat model of anorexia nervosa. Int. J. Eat. Disord. 2020, 53, 432-446. [CrossRef] [PubMed] 
125. Romero, J.; Garcia, L.; Fernández-Ruiz, J.; Cebeira, M.; Ramos, J. Changes in rat brain cannabinoid binding sites after acute or chronic exposure to their endogenous agonist, anandamide, or to 89-tetrahydrocannabinol. Pharmacol. Biochem. Behav. 1995, 51, 731-737. [CrossRef]

126. Casteels, C.; Gérard, N.; Van Kuyck, K.; Pottel, L.; Nuttin, B.; Bormans, G.; Van Laere, K. Small animal PET imaging of the type 1 cannabinoid receptor in a rodent model for anorexia nervosa. Eur. J. Nucl. Med. Mol. Imaging 2013, 41, 308-321. [CrossRef] [PubMed]

127. Gérard, N.; Pieters, G.; Goffin, K.; Bormans, G.; Van Laere, K. Brain Type 1 Cannabinoid Receptor Availability in Patients with Anorexia and Bulimia Nervosa. Biol. Psychiatry 2011, 70, 777-784. [CrossRef] [PubMed]

128. Kaye, W.H. Neurobiology of anorexia and bulimia nervosa. Physiol. Behav. 2008, 94, 121-135. [CrossRef] [PubMed]

129. Kirkham, T.C.; Williams, C.M.; Fezza, F.; Di Marzo, V. Endocannabinoid levels in rat limbic forebrain and hypothalamus in relation to fasting, feeding and satiation: Stimulation of eating by 2-arachidonoyl glycerol. Br. J. Pharmacol. 2002, 136, 550-557. [CrossRef]

130. Hanus, L.O.; Avraham, Y.; Ben-Shushan, D.; Zolotarev, O.; Berry, E.M.; Mechoulam, R. Short-term fasting and prolonged semistarvation have opposite effects on 2-AG levels in mouse brain. Brain Res. 2003, 983, 144-151. [CrossRef]

131. Fride, E.; Bregman, T.; Kirkham, T.C. Endocannabinoids and Food Intake: Newborn Suckling and Appetite Regulation in Adulthood. Exp. Biol. Med. 2005, 230, 225-234. [CrossRef]

132. Frieling, H.; Albrecht, H.; Jedtberg, S.; Gozner, A.; Lenz, B.; Wilhelm, J.; Hillemacher, T.; De Zwaan, M.; Kornhuber, J.; Bleich, S. Elevated cannabinoid 1 receptor mRNA is linked to eating disorder related behavior and attitudes in females with eating disorders. Psychoneuroendocrinology 2009, 34, 620-624. [CrossRef]

133. Ceccarini, J.; Weltens, N.; Ly, H.G.; Tack, J.; Van Oudenhove, L.; Van Laere, K. Association between cerebral cannabinoid 1 receptor availability and body mass index in patients with food intake disorders and healthy subjects: A [(18)F]MK-9470 PET study. Transl. Psychiatry 2016, 6, e853. [CrossRef] [PubMed]

134. Hillard, C.J. Stress regulates endocannabinoid-CB1 receptor signaling. Semin. Immunol. 2014, 26, 380-388. [CrossRef] [PubMed]

135. Koethe, D.; Llenos, I.C.; Dulay, J.R.; Hoyer, C.; Torrey, E.F.; Leweke, F.M.; Weis, S. Expression of CB1 cannabinoid receptor in the anterior cingulate cortex in schizophrenia, bipolar disorder, and major depression. J. Neural Transm. 2007, 114, 1055-1063. [CrossRef] [PubMed]

136. Patel, S.; Hillard, C.J. Role of Endocannabinoid Signaling in Anxiety and Depression. Curr. Top. Behav. Neurosci. $2009,1,347-371$. [CrossRef]

137. Agrawal, A.; Nelson, E.C.; Littlefield, A.K.; Bucholz, K.K.; Degenhardt, L.; Henders, A.K.; Madden, P.A.F.; Martin, N.G.; Montgomery, G.W.; Pergadia, M.L.; et al. Cannabinoid Receptor Genotype Moderation of the Effects of Childhood Physical Abuse on Anhedonia and Depression. Arch. Gen. Psychiatry 2012, 69, 732-740. [CrossRef]

138. Kong, X.; Miao, Q.; Lu, X.; Zhang, Z.; Chen, M.; Zhang, J.; Zhai, J. The association of endocannabinoid receptor genes (CNR1 and CNR2) polymorphisms with depression. Medicine 2019, 98, e17403. [CrossRef]

139. Huebel, C.; Marzi, S.J.; Breen, G.; Bulik, C.M. Epigenetics in eating disorders: A systematic review. Mol. Psychiatry 2019, 24, 901-915. [CrossRef]

140. Chowdhury, T.G.; Chen, Y.-W.; Aoki, C. Using the Activity-based Anorexia Rodent Model to Study the Neurobiological Basis of Anorexia Nervosa. J. Vis. Exp. 2015, 10, e52927. [CrossRef]

141. Klenotich, S.J.; Dulawa, S.C. The Activity-Based Anorexia Mouse Model. Methods Mol. Biol. 2011, 829, 377-393. [CrossRef]

142. Scherma, M.; Satta, V.; Collu, R.; Boi, M.F.; Usai, P.; Fratta, W.; Fadda, P. Cannabinoid CB1/CB2receptor agonists attenuate hyperactivity and body weight loss in a rat model of activity-based anorexia. Br. J. Pharmacol. 2017, 174, 2682-2695. [CrossRef]

143. Nilsson, I.A.K. The anx/anx Mouse-A Valuable Resource in Anorexia Nervosa Research. Front. Neurosci. 2019, 13, 59. [CrossRef] [PubMed]

144. D'Addario, C. University of Teramo: Teramo, Italy, 2020; Unpublished work.

145. Mukhopadhyay, B.; Liu, J.; Osei-Hyiaman, D.; Godlewski, G.; Mukhopadhyay, P.; Wang, L.; Jeong, W.-I.; Gao, B.; Duester, G.; Mackie, K.; et al. Transcriptional Regulation of Cannabinoid Receptor-1 Expression in the Liver by Retinoic Acid Acting via Retinoic Acid Receptor- $\gamma$. J. Biol. Chem. 2010, 285, 19002-19011. [CrossRef] [PubMed]

146. Moraitis, A.G.; Block, T.; Nguyen, D.; Belanoff, J.K. The role of glucocorticoid receptors in metabolic syndrome and psychiatric illness. J. Steroid Biochem. Mol. Biol. 2017, 165, 114-120. [CrossRef] [PubMed]

147. Geer, E.B.; Islam, J.; Buettner, C. Mechanisms of Glucocorticoid-Induced Insulin Resistance. Endocrinol. Metab. Clin. N. Am. 2014, 43, 75-102. [CrossRef] [PubMed]

148. Majer-Łobodzińska, A.; Adamiec-Mroczek, J. Glucocorticoid receptor polymorphism in obesity and glucose homeostasis. Adv. Clin. Exp. Med. 2017, 26, 143-148. [CrossRef]

149. Sidibeh, C.O.; Pereira, M.J.; Börjesson, J.L.; Kamble, P.G.; Skrtic, S.; Katsogiannos, P.; Sundbom, M.; Svensson, M.K.; Eriksson, J.W. Role of cannabinoid receptor 1 in human adipose tissue for lipolysis regulation and insulin resistance. Endocrine 2017, 55, 839-852. [CrossRef]

150. Hilbert, A. Binge-Eating Disorder. Psychiatr. Clin. N. Am. 2019, 42, 33-43. [CrossRef]

151. De Zwaan, M. Binge eating disorder and obesity. Int. J. Obes. 2001, 25, S51-S55. [CrossRef]

152. Chen, B.; Hu, N. Rimonabant improves metabolic parameters partially attributed to restoration of high voltage-activated Ca2+ channels in skeletal muscle in HFD-fed mice. Braz. J. Med. Biol. Res. 2017, 50, e6141. [CrossRef] 
153. Satta, V.; Scherma, M.; Piscitelli, F.; Usai, P.; Castelli, M.P.; Bisogno, T.; Fratta, W.; Fadda, P. Limited Access to a High Fat Diet Alters Endocannabinoid Tone in Female Rats. Front. Neurosci. 2018, 12, 40. [CrossRef]

154. Parylak, S.L.; Koob, G.F.; Zorrilla, E.P. The dark side of food addiction. Physiol. Behav. 2011, 104, 149-156. [CrossRef] [PubMed]

155. Marcos, M.; Pastor, I.; De La Calle, C.; Laso, F.-J.; Barrio-Real, L.; González-Sarmiento, R. Cannabinoid Receptor 1 Gene is Associated with Alcohol Dependence. Alcohol. Clin. Exp. Res. 2011, 36, 267-271. [CrossRef] [PubMed]

156. Proudnikov, D.; Kroslak, T.; Sipe, J.C.; Randesi, M.; Li, D.; Hamon, S.; Ho, A.; Ott, J.; Kreek, M.J. Association of polymorphisms of the cannabinoid receptor (CNR1) and fatty acid amide hydrolase (FAAH) genes with heroin addiction: Impact of long repeats of CNR1. Pharm. J. 2010, 10, 232-242. [CrossRef] [PubMed]

157. Schmidt, L.G.; Samochowiec, J.; Finckh, U.; Fiszer-Piosik, E.; Horodnicki, J.; Wendel, B.; Rommelspacher, H.; Hoehe, M.R. Association of a CB1 cannabinoid receptor gene (CNR1) polymorphism with severe alcohol dependence. Drug Alcohol Depend. 2002, 65, 221-224. [CrossRef]

158. Zhou, Y.; Huang, T.; Lee, F.; Kreek, M.J. Involvement of Endocannabinoids in Alcohol “Binge” Drinking: Studies of Mice with Human Fatty Acid Amide Hydrolase Genetic Variation and After CB1 Receptor Antagonists. Alcohol. Clin. Exp. Res. 2016, 40, 467-473. [CrossRef] [PubMed]

159. Pucci, M.; Di Bonaventura, M.V.M.; Zaplatic, E.; Bellia, F.; Maccarrone, M.; Cifani, C.; D'Addario, C. Transcriptional regulation of the endocannabinoid system in a rat model of binge-eating behavior reveals a selective modulation of the hypothalamic fatty acid amide hydrolase gene. Int. J. Eat. Disord. 2018, 52, 51-60. [CrossRef]

160. Bulik, C.M.; Yilmaz, Z.; Hardaway, J.A. Genetics and epigenetics of eating disorders. Adv. Genom. Genet. 2015, 5, 131-150. [CrossRef]

161. Mancino, S.; Burokas, A.; Gutiérrez-Cuesta, J.; Gutiérrez-Martos, M.; Martín-García, E.; Pucci, M.; Falconi, A.; D’Addario, C.; Maccarrone, M.; Maldonado, R. Epigenetic and Proteomic Expression Changes Promoted by Eating Addictive-Like Behavior. Neuropsychopharmacology 2015, 40, 2788-2800. [CrossRef]

162. Domingo-Rodriguez, L.; De Azua, I.R.; Dominguez, E.; Senabre, E.; Serra, I.; Kummer, S.; Navandar, M.; Baddenhausen, S.; Hofmann, C.; Andero, R.; et al. A specific prelimbic-nucleus accumbens pathway controls resilience versus vulnerability to food addiction. Nat. Commun. 2020, 11, 1-16. [CrossRef] 